\title{
TRANSFORMATION OF MAQÂSHID Al-SYARI'AH (An Overview of the Development of Islamic Law in Indonesia)
}

\author{
Absori \\ (Fakultas Hukum Universitas Muhammadiyah Surakarta, Jln A. Yani Tromol Pos 1, \\ Pabelan Kartasura, Email: absori_ums@yahoo.co.id) \\ Aidul Fitriciada Azhari \\ (Sekolah Pascasarjana Universitas Muhammadiyah Surakarta, Jln A. Yani Tromol \\ Pos 1, Pabelan Kartasura, Email: aidul.f.azhari@ums.ac.id) \\ M. Mu'inudinillah Basri \\ (Sekolah Pascasarjana Universitas Muhammadiyah Surakarta, Jln A. Yani Tromol \\ Pos 1, Pabelan Kartasura, Email: basri_salam@yahoo.com) \\ Fatkhul Muin \\ (Fakultas Hukum UNTIRTA Banten, Jln. Raya Jakarta KM. 4 Pakupatan Serang \\ Banten, Email: fatkhulmoen@gmail.com)
}

\begin{abstract}
:
This study is part of an effort to systematize the basic conception of the values of the sharia as the foundation in the life of nation and state life, where the orientation is to embody the essence of the religious life through the maqâshid al-syarîah. Islam as al-dîn has been providing the basics of life of Muslims through the al-Qur'an and as-Sunnah. Both of these contain guidance values of human life, including in running the sharia for Muslims. Sharia (syarîah) in perspective of terminology is "street". In an isthilâhî perspective, it is a way to get to God. The basic meaning of sharia itself should be realized in the basic understanding maqâshid al-syarîah, which can be interpreted within the scope of statehood, because the meaning contained are the values of universality of maqâshid al-syarîah. In the context of Indonesian, then maqâshid al-syarîah is part of the basic conception air Almighty God with the aim of creating prosperity for the people of Indonesia. In this study, the approach used is the doctrinal bases to study literature. This study is the strengthening of the maqâshid al-syarîah as the basis for the development of Islamic law.
\end{abstract}

\section{Key Words:}

Maqâshid al-syarî̀ah, Islamic Law, Development of Islamic Law, Mashlahah

al-1hkâm Vol.11 No.1 Juni 2016

DOI: http://dx.doi.org/10.19105/al-ihkam.v11i1.854 


\begin{abstract}
Abstrak:
Kajian ini merupakan bagian dari upaya untuk sistematisasi konsep dasar dari nilai-nilai syari'ah sebagai pondasi dalam kehidupan berbangsa dan kehidupan bernegara, dimana orientasi tersebut adalah untuk mewujudkan hakikat kehidupan dalam beragama melalui maqâshid al-syarîah. Islam sebagai al-dîn telah memberikan dasar-dasar kehidupan umat Muslim melalui al-Qur'an dan alSunnah. Kedua hal tersebut mengandung nilai-nilai tuntunan kehidupan umat manusia termasuk dalam menjalankan syariah bagi umat Muslim. Syari'ah dalam perspektif terminologi merupakan "jalan". Sedangkan secara isthilâhî, ia dimaknai sebagai jalan untuk sampai kepada Allah SWT. Makna dasar dari syari'ah itu sendiri harus diwujudkan dalam pemahaman dasar maqâshid al-syarî'ah, di mana dapat dimaknai dalam cakupan kehidupan bernegara, karena makna yang terkandung adalah nilai-nilai universalitas dari maqâshid al-syarîah. Dalam konteks keindonesiaan, maka maqâshid al-syarîah merupakan bagian dari konsepsi dasar berketuhanan Yang Maha Esa dengan tujuan menciptakan kesejahteraan bagi rakyat Indonesia. Dalam kajian ini, pendekatan yang digunakan adalah pendekatan doktrinal dengan mendasarkan kepada kajian kepustakaan. Kajian ini merupakan penguatan maqâshid al-syarîah sebagai dasar pembangunan hukum Islam.
\end{abstract}

\title{
Kata-kata Kunci: \\ Maqâshid al-syarî‘ah, Hukum Islam, Pembangunan Hukum Islam, Mashlahah
}

\section{Introduction}

The dynamic of problems in Islam cannot be separated from nash, for example, it is clearly stated in the Qur'an that Allah justifies trading and forbids usury. However, in the present context the understanding of the texts obscured by a variety of mu âmalah practices that are contrary to the principles of Islamic laws, such as various usury activities undertaken by banks. According to Lukman S. Tahir, there are two trends that are usually used by scholars in seeing the issue of God, religion, and society. Both of these trends are as follows:

1. Transcendental-speculative trend; a trend that put the God as a superior power and detached from the real world that exists in 
society. God is described as a more metaphysical one and do not touch the human dimension which is imperfect.

2. Trend in a historical and deductive-monolithic; a trend that presents Islam which is not actual Islam but rather is based on the Islam in the early and middle age of Islam. Its reference is the classic Islam. ${ }^{1}$

Both are parts of a trend on the development of Islam from time to time which are floating and above the ground. Actually, Islam as al-dinn, is well positioned as the road to wisdom and maw'izhah hasanah. Such basic conception builds an understanding of the essential meaning of Islam which is as rahmatan li al-'âlamîn. The fundamental values of Islam are derived from the Qur'an and Sunnah as basic guidance in performing Islamic law totally. It is reflected on all the commands that have been determined by Allah and His Messenger, so it is the duty of human as a servant to obey all His orders.

According to Fazrul Rahman, the Qur'an revolves around three things, among others ${ }^{2}$ :

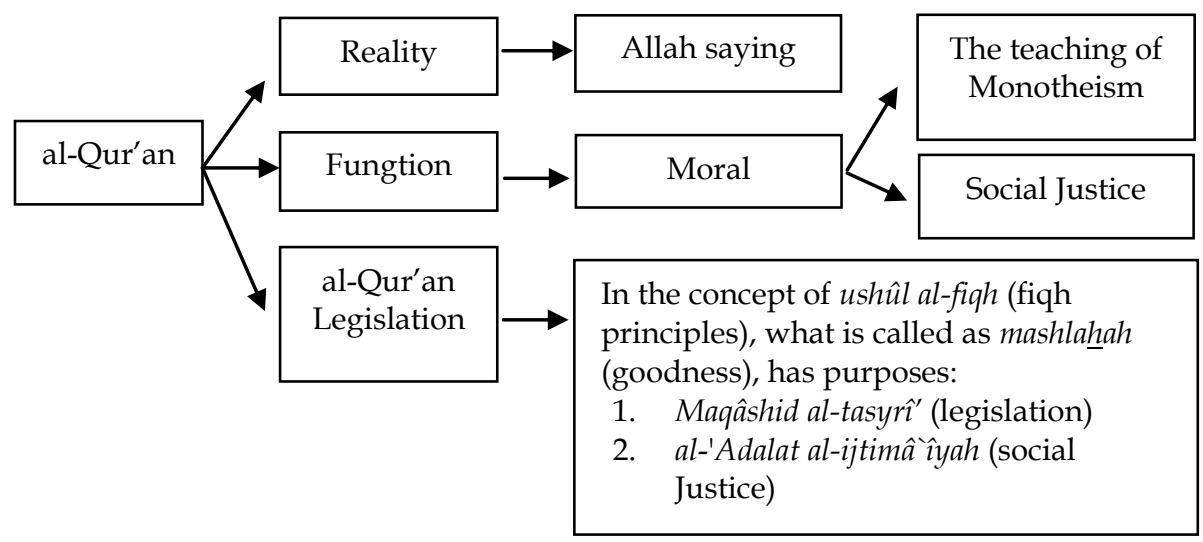

1 Rahimin Affandi Abdul Rahim, et. al, Pendekatan Baru Maqasid al-Sharî'ah dalam Pengajian Syarî'ah di Malaysia: Satu Analisis, This article is adopted from worksheets presented in International Conference: Islamic Jurisprudence and the Challenges of the 21st Century, Anjuran UIAM, (8 Agustus 2006), 52-53.

2 Ghufron A. Mas'adi, Pemikiran Fazlul Rahman tentang Metedologi Pembaharuan Hukum Islam (Jakarta: Rajagrafindo, 1997), 114. 
In the view of Kuntowijoyo, the meaning of transcendence in the sense of belief in Allah, derived from Q.S Ali 'Imran (3): 110.

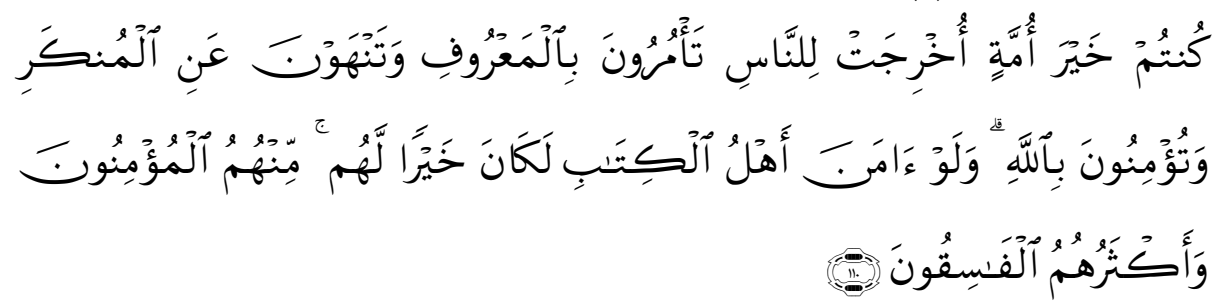

You are the best nation produced [as an example] for mankind. You enjoin what is right and forbid what is wrong and believe in Allah. If only the People of the Scripture had believed, it would have been better for them. Among them are believers, but most of them are defiantly disobedient.

Referring to this verse, Kuntowijoyo places three pillars in Social Sciences he offers. First: prophetic namely 'humanization' (ta'murûna bi al-ma'rûf); second: liberation (tanhawna 'an al-munkar); and third: transcendence (tu'minûna bi Allah). ${ }^{3}$ These pillars will be used as a basis to develop prophetic jurisprudence and characterizing its paradigm. His emphasis on the notion that transcendence must be the basis of these two elements shows Kuntowijoyo's attention to the significance of religion in the process of theory building in the social sciences (as well as in the jurisprudence). Through transcendence, the prophetic jurisprudence would make the religion values as an important part of the process civilization development. ${ }^{4}$

The prophetic jurisprudence as one of the pillars in the development of Islamic law relates to the maqûshid. The maqâshid itself as a base in the reformulation of Islamic law through the ushûl al-figh (a discipline on figh rules). According to al-Syâthibî, there are four ways to understand maqâshid al-syarî'ah: ${ }^{5}$

3 Khudzaifah Dimyati, Pemikiran Hukum, Konstruksi Epistimologis Berbasis Budaya Hukum Indonesia (Yogyakarta: Genta Publishing, 2014), 130.

4 Ibid., 130.

5 Asmuni Mth, et.al, Pribumisasi Hukum Islam, Pembacaan Kontemporer Hukum Islam di Indonesia (Perangkat Teoritik dan Metode Perumusan Maqashid al-Syariah al-Syâthibi) (Yogyakarta, Kaukaba, 2012), 102. In addition, each religion must maintain its law consistently, for it is a disposition given by God to His creatures to serve as life guidance. Al-Syâthibî also confirms that all religions and other faiths have values as promoted by Islam, namely to preserve religion (hifzh al-din), to nourish the soul (hifzh al-nafs), to maintain mind (hifzh al-'aql), to keep descendants (hifzh al-nasl) and to 
a. The clarity of the principles of command and prohibition

b. Paying attention to al-'illah (causes) for a command and prohibition.

c. Observing al-mashlahah (goodness) that follows a command or prohibition.

d. Sharia reticence about an agreement and motives of the agreement.

With regard to the thought about maqâshid, According to Ibn Taymiyya, shari'a comes to bring benefits (mashlahah) and get rid of any destruction (mafsâdât). Ibn Taymiyya does not agree with the scope of al-dlarûriyyât al-khams which is limited to five aspects; hifzh almâl, al-nafs, al-dîn, al-nasl, al-'aql (protecting wealth, soul, religion, descendants, and mind) because for him maqâshid also includes other meanings such as love and fear of Allah, sincerity in religion and to do based on such sincerity. ${ }^{6}$ According to Ibn Taymiyya, God commands his servant to make every effort to hold on the almashlahah, and keep away from mafsadâh and so on.7 The existence of the benefits (al-mashlahah) is the primary indictor for maqâshid alsyarî'ah to come into being, so, with the al-mashlahah (benefits) there will not be mafsadat (destruction) to the people.

The principle of mashlahah is a dream or goal of Shari'a (maqâshid al-tasyrî'), in order to maintain and protect the holistic five (al-muhâafazhah' alâa al-kulliyah al-khams), consisting of: ${ }^{8}$

1. Hifzh al-din, securing the enforcement of the right to have a religion and freedom of being religious;

2. Hifzh al-nafs, guaranteeing the right to live;

3. Hifzh al-nasl, guaranteeing the right to have descendants;

4. Hifzh al-'aql, freedom to think, to argue, and to have education;

5. Hifzh al-amal, freedom to work, to get a job, to manage and exploit natural resources, and the right to own property.

maintain deeds (hifzh al-`amal). See al-Syâthibî, al-Muwâfaqât fi Ushûl al-Syarî'ah, Section II (Beirut: Dâr al-Kutub al'Ilmiyyah, n.t), p. 8. See also Zuhairi Misrawi, AlQur'an Kitab Toleransi, Tafsir Tematik Islam Rahmatan Lil'Alamin (Jakarta: Pustaka Oasis, 2010), 230.

${ }^{6}$ Asmuni Mth, et. al. Pribumisasi Hukum Islam, 142.

7 Ibid., 143.

8 Abd Shomad, Hukum Islam Penormaan Prinsip Syariah dalam Hukum di Indonesia (Jakarta: Kencana, 2010), 62-63. 
In the process, there is a shift of paradigm; from classic maqâshid to the contemporary one: ${ }^{9}$

\begin{tabular}{|l|l|l|}
\hline No & \multicolumn{1}{|c|}{$\begin{array}{c}\text { The Classical Theory of } \\
\text { Maqâsid }\end{array}$} & $\begin{array}{l}\text { The Contemporary Theory of } \\
\text { Maqâsid }\end{array}$ \\
\hline 1 & $\begin{array}{l}\text { Protecting descendants } \\
(a l-n a s l)\end{array}$ & $\begin{array}{l}\text { It is a theory which is oriented } \\
\text { to the protection of the famil } \\
\text { and more concern about the } \\
\text { family institution. }\end{array}$ \\
\hline 2 & Protecting the mind (al- aql) & $\begin{array}{l}\text { It doubles a mindset and } \\
\text { scientific researches; } \\
\text { prioritizing a journey to seek } \\
\text { knowledge; pressing the } \\
\text { mindset that puts a crime mob } \\
\text { as priority; avoid attempts to } \\
\text { belittle the works of the brain. }\end{array}$ \\
\hline 3 & $\begin{array}{l}\text { Protecting the honor }(a l- \\
\text { iradl); Protecting the soul }(a l- \\
n a f s)\end{array}$ & $\begin{array}{l}\text { It maintains and protect human } \\
\text { dignity; it maintains and } \\
\text { protect human rights. }\end{array}$ \\
\hline 4 & $\begin{array}{l}\text { Protecting the religion }(a l- \\
\text { dinn })\end{array}$ & $\begin{array}{l}\text { It maintains, protects and } \\
\text { respects the freedom to have a } \\
\text { religion and belief. }\end{array}$ \\
\hline 5 & $\begin{array}{l}\text { Protecting wealth (al-mâl }) \\
\text { it prioritizes social care; pays } \\
\text { attention to economic } \\
\text { development and growth; } \\
\text { encourages human welfare; } \\
\text { eliminates the gap between the } \\
\text { rich and the poor. }\end{array}$ \\
\hline
\end{tabular}

Maqâshid syarî'ah is the value of Islamic law which is closely associated with the study of ushîl al-figh and figh (Islamic jurisprudence) which initially it is only a small part in the study of the ushûl al-figh. The essence of it discusses about the purpose and wisdom of the shari'a laws, which covers three areas; the first is worship (ritual). The second is mu âmalah (social interaction), and the

\footnotetext{
9 Absori, et. al. Hukum Profetik, Kritik terhadap Paradigma Hukum Non Sistemik
} (Yogyakarta: Genta Publishing, 2015), 261-262. 
third is jinâyah (criminal). The study of maqâshid al-syarî'ah can also be classified as a part of the philosophy of Islamic law. ${ }^{10}$ This is what makes the maqâshid al-syarî'ah is important to study to work for the benefits (mashlahah) of a law which is, later, to be enacted into legislation.

The benefit (mashlahah) is the realization of the basic values of Islam contained in the Qur'an and Sunnah as religion which is rahmatan li al-'âlamîn. In this study, there are two main issues, namely how does Islamic law creates al-'adalah al-ijtimâ'îyah (social justice) and how is the maqâshid syarî'ah as a basis for the development of Islamic law in Indonesia based on the principle of mashlahah?

\section{Islamic Law in the Framework of al-'Adalah al-Ijtimâ' $̂ y a h$ (Social Justice)}

Al-'adalah al-ijtimâ'îyah (social justice) is the basic idea in the life of the nation, which also means as an attempt to create social justice for the people. In the context of Indonesia, it is in this sense that it relates to the meaning of the independence of Indonesia that will be realized through the state fundamental norm, which is to create justice for the people of Indonesia. Islam is a religion of the majority of the people in Indonesia, in which Islam is inseparable from the roles Muslims play in various aspects of life of the nation. The dynamic of Islamic law in Indonesia can be seen within a few decades, and the progress needs to be portrayed as a basic necessity for the Indonesian people to the system of Islamic law in the national law.

In the perspective of Islam, the Islamic law itself is often referred to by several terms, each of which illustrates the side or specific characteristics of the law. There are at least four names that are often linked to the Islamic law, as follows:

1. Sharia, which is usually used in two senses, in a broad and narrow sense. In a broad sense, sharia refers to a set of norms or instructions derived from divine revelation to set belief

\footnotetext{
10 Ghilman Nursidin, Konstruksi Pemikiran Maqhasid Syariah Imam al-Haramain alJuwaini (Kajian Sosio-Histroris), http://eprints.walisongo.ac.id/116/1/Ghilman_Tesis_Sinopsis.pdf. (retrieved on April 11, 2015).
} 
system and concrete behavior of human in the dimension of relationship. Thus, the sharia in the broad sense includes two aspects of Islam, the faith and mu âmalah (human interaction). However, in a narrow sense, the concept of sharia is not exactly the same as the concept of law because sharia not only contains legal norms per se, with punishment that can be upheld by force, but also includes both religious faith, morality and social norms.

2. Fiqh, which is usually used to refer to Islamic law. The term is usually used in two meanings. First, it is used in the sense of jurisprudence, so that figh refers to the branch of studies examined the Islamic law. Second, it is used in the sense of the law itself.

3. Syar` Law, it refers to units of norms or rules. The set of norms or syara' law forms sharia or fiqh. They encompasses both takliffi norms, such as the obligation, sunnah (recommended), mubâh (permissible), makrûh (not recommended) and haram (forbidden); and wadl'î norms such as causes, conditons and obstructions.

4. Qanûn. According to Syamsul Anwar, the qanûn describes part of sharia which has been integrated into state law by the government, such as marriage law (Act No. 1 of 1974), waqf law (Law No. 41 of 2004), and some others. In addition, the qanûn also refers to various regulations issued by the Islamic states in order to implement sharia and fill in the void and complete the sharia. The action is called siyâsah syar' $\hat{y} y a h .11$

Islamic law itself is a representation of Islamic thought, the most typical manifestation of the worldview of Islam, and the essence of Islam itself. Islamic law is an instructive example of a "divine law". This law is a phenomenon that is very different from all the legal forms which, nevertheless, is certainly not always leading and decisive. ${ }^{12}$ It depends on the context where the law is in force.

${ }^{11}$ Mustofa and Abdul Wahid, Hukum Islam Kontemporer (Jakarta, Sinar Grafika, 2013), 1-3.

12 Joseph Schacht, Pengantar Hukum Islam, trans. Joko Supomo (Bandung: Nuansa, 2010), 22-23. 
According to al-Ghazâlî, the purposes of Islamic Sharia are five; maintain (guarantee and protect) religion, soul, mind, descendants, and properties. all that includes protections of the five things are categorized as goodness (mashlahah) and all that threaten the safety or harm the five things is categorized as mafsadah and the efforts to avoid it is also a mashlahah. ${ }^{13}$ As laws derived from the Qur'an and al-Sunnah, Islamic law has its own characteristics that distinguish it from other laws, as follows:

a. Divine sapiential; Islamic law is the radiance of the wisdom values of God through His revelation, both form of the Qur'an and the Sunnah which are the main sources. It is a religious law whose implementation is an integral part of the actualization of the teachings of the religion.

b. Universal humanistic; Islamic law is a reflection of God's love for humanity. That is why, Islamic law respects human values, upholding human dignity as the noblest creatures.

c. Dynamic and flexible; the nature of Islamic law is dynamic because it has the power to adapt to local wisdom, though it is universal in nature.

d. Balanced; Islamic law always maintain the balance between individual and social values, between the private and public values, between spiritual and material values, between the vertical and horizontal relations, and between the life in world and hereafter. These are reflected in the formulation of laws that are not extreme.

e. Practical and applicable; Islamic law is a law that can be practiced and applied in real life. It has a theory and idealism that make it possible to implement in all circumstances, both in normal and emergency situation.

f. Ideal and realistic; Islamic law also has ideal and realistic characteristics and does not impose a law that is beyond human ability.

g. Moderate; Islamic law chooses a moderate position, it does not take the extreme right or left position. Islamic law forbids

\footnotetext{
13 Anang Haris Himawan, et. al, Epistimologi Syar'̂̂, Mencari Format Baru Fiqih Indonesia (Yogyakarta: Pustaka Pelajar, 2000), 91.
} 
overly concerned with spiritual aspects and forget about physical aspects.

h. Just; God has uphold justice on earth and in the sky and commands His creatures to enforce and implement it.

i. Bring benefits (jalb al-mashâlih); Islamic law is always in synergy with human welfare. For that to happen, it makes the benefits (mashlahah) as the most principal purpose of the law to be achieved through legal formulations stipulated. ${ }^{14}$

The characteristics are parts of an effort made to create the principles of mashlahah (benefits) for the mankind which is built on the values of the Qur'an and the Sunnah as the basis of social life.

\section{Maqâshid al-Syarî'ah: The Basis of the Building of Islamic Law In the Framework of National Law}

The position of Islam as a source of law in Indonesia can be seen in the social situations as a portrait of life, where the majority of Indonesia's population is Muslim, but does not deny religion other than Islam as part of the constitutional mandate that gives freedom of having religion and worship in accordance with his beliefs.

In relation to Islamic law, historically in the 17th century, the Dutch began removing the existence of Islamic law. Through the trade office of the Dutch (VOC 1602-1880), on May 25, 1760 issued by Resolutie der Indesche Regeering which contains provisions of enactment of a set of rules of marriage and inheritance according to Islam. This resolution which is known as Compendium Freiyer, within certain limits, can be regarded as the first legislation of Islamic law in Indonesia. ${ }^{15}$

Discourse on constitution in Indonesia cannot be separated from Islamic law. It is associated with the Jakarta Charter signed in June 22, 1945 which determines the obligation to implement Islamic law for its adherents. However, after the formulation of the Jakarta Charter has been changed by removing the obligation to implement the Islamic law, then there was a debate about the constitutional

14 Muhammad Syafii Antonio, et. al, "Ensiklopedia Leadership", in Malthuf Siroj, Pembaharuan Hukum Islam di Indonesia, Telaah Kompilasi Hukum Islam (Yogyakarta: Pustaka Ilmu, 2012), 88-94.

15 Absori, et. al, Hukum Profetik, 382. 
legality of Islamic law in the national legal system. ${ }^{16}$ The recognition and constitutional guarantees was later reinforced by the MPR (provisional people's consultative assembly) of Indonesia through the Fourth Amendment of the 1945 Constitution, on August 10, 2002 which sets: the 1945 Constitution which was set on August 18, 1945 and was reinforced with Presidential Decree on July 5, 1959 and confirmed by acclamation on July 22, 1959 by the Parliament. The enactment of the Fourth Amendment of the 1945 Constitution reaffirms the position of Presidential Decree which issued in July 5, 1959, also recognizes Islamic law embodied in the Jakarta Charter Jakarta. Thus, the recognition and constitutional guarantees on the enforcement of Islamic law in Indonesia is getting stronger with the stipulation by the People's Consultative Assembly (MPR) which, according to the 1945 constitution, is an institution that has the authority to stipulate constitutions. ${ }^{17}$

In the social perspective of Muslims in Indonesia, it can be seen from the view of Abdurrahman that how the importance of Islamic law for the nation and state in Indonesia can be seen in three aspects:

1. In reality, Muslim not merely constitutes the majority in Indonesia, but also represents the largest group of Muslims in the world. It means that Islamic law as the law that is created for and applied especially to the people is the law with great subjects. So, in all circumstances, Islamic law has a very strategic position not only for Indonesian Muslims, but the Islamic world in general, and it also has a strategic position in the Indonesian legal system. However, the significance of which will contribute greatly depends on the position and status of Muslims to be ready to apply the law. It will have values that are more important when Muslims treat and implement its provisions as well as possible, otherwise, it could cause a negative impact on the position of the Islamic law itself.

\footnotetext{
16 Aidul Fitriacida Azhari, Catatan Kritis Konstitusi, Hukum Tata Negara, Politik, Hukum Islam (Solo: Penerbit Nutrisi Peradaban, 2009), 313.

17 Ibid., 315-316.
} 
2. Although the Republic of Indonesia is not an Islamic state, by setting Pancasila (the Five Principles) as the state foundation and the only principle in the life of the nation and state, it is implied that Islamic law occupies a very important position. The first; belief in God the Almighty which is in line with the teachings of monotheism that are the essence of the teachings of Islam and Islamic law, provides the ideal basis sturdy enough to carry out the provisions of Islamic law in the state of law that is based on the Pancasila. In 1945 Constitution, it is also confirmed that the state guarantees the freedom of each citizen to have his own religion and to worship according to their religion or beliefs. This constitutional basis is a formal assurance of every Muslim and Muslims in Indonesia to implement Islamic law in the life of the community and the nation of Indonesia as well as in the life of the state.

3. In the framework of developing the nation and the Republic of Indonesia, national law has been one of the fields to develop. For several centuries, we have been busy with various activities to design what and how national law would take the form. In such process, Islamic law has greater chances to be included as one of the basic and indispensable materials to foster the national law, besides other legal materials such as those derived from Western law and customary law. In this regard, when the Islamic law is intended to get a larger place in the upcoming National law it must be able to show its superiority to other laws. ${ }^{18}$

It gives an overview of the construction of Islamic law in Indonesia in the context of the national law development, so that the constitutional rights in terms of having a religion are not interpreted in an abstract meaning, but rather give a concrete meaning through formal legal which has material values as the basis for strengthening Islamic legal system in the development of national law.

According to Alwi Shihab cited by Amiur Nuruddin and Azhari Akmal Tarigan, in general, the policy of the Islamic law in

${ }^{18}$ Abdurrahman, Kompilasi Hukum Islam di Indonesia (Jakarta: Akademika Pressindo, 1992), $2-4$. 
force in Indonesia before independence as suggested by Snouck Hurgronje is based on the three main principles: ${ }^{19}$

1. In all religious ritual issues, or worship aspect in Islam, the people of Indonesia should have freedom of performing it. The logic behind this policy is to allow the belief in the minds of many people to emerge that the Dutch colonial government does not intervene in their faith. These are areas which are sensitive to the Muslims because it touches on the values of their deepest religiousness. By doing so, the government will successfully capture the hearts of many Muslims and tame them and along with it will reduce, if not totally eliminate, the influence of the resistance of "Muslim fanatics" against the colonial government.

2. In relation to the Islam social institutions, or $m u$ 'âmalah aspects in Islam such as marriage, inheritance, waqf, and other social relations, the government should strive to maintain and appreciate its existence. Nevertheless, the government should try to attract the attention of the Indonesian people towards the advantages that can be gained from the western culture. This is done with the hope that they are willing to replace the social institutions of Islam over social institutions in the West.

3. Most importantly, in the political issues, the government is advised to not tolerate any activities carried out by Muslims to spread the appeals of Pan-Islamism which can cause political or armed resistance against colonial government.

Carel Frederik Winter, an oldest expert on Java issues, Javaichi, who was born and died in Yogyakarta (1799-1857), Solomon Keuzer (1823-1868) a guru of linguistic and cultural science of the Dutch, and Prof. Mr. Lodewijke Christian Willem Van den Berg (1845-1927), who in 1845 wrote a book Muhammadansch Rechts (Principles of Islamic law), state that, "Islamic law is necessary for the people of Islam natives although with some deviations". ${ }^{20}$ Besides, in general, the

19 Amiur Nuruddin and Azhari Akmal Tarigan, Hukum Perdata Islam di Indonesia, (Studi Kritis Perkembangan Hukum Islam dari Fikih, UU No. 1/1974 sampai KIH) (Jakarta: Kanana, 2004), 16.

20 Sayuti Thalib, "Receptio a Contrario, (Hubungan Hukum Adat dengan Hukum Islam)", in Mohd. Idris Ramulyo, Asas-asas Hukum Islam, Sejarah Timbul dan 
conflict of legal system in Indonesia is driven by the needs of colonialism at that time, the conflict develops because of the two systems of law (west and customary law) which is fully supported by the ruler of that time. It can be seen from the discriminative political laws against Islamic law and the efforts of authorities to downplay the role and functions of religious courts. The situation during the period has caused Islam as a religion can only be exercised in the ritual aspect alone, so that the movements of Muslims did not develop significantly. In the decades after the Indonesia independence, the position of Islamic law did not have a room that is significant, this is because the legal system built over decades of government fill public spaces more with the system of laws of the Netherlands, so the development of Islamic law in Indonesia as a source of national law does not develop significantly.

As a religion that regulates the life and human livelihood, the basic values and norms of fundamental Islam provides basic standards regarding various socio-cultural activities of man. Thus, the social system of Islamic culture (such as political, economic, social, education system, and so on) is based on sharia (worship and mu âmalah), Islamic morality, and Islamic theology. ${ }^{21}$ One of ideas of the birth of Islamic law after the independence and which can be

Berkembangnya Kedudukan Hukum Islam dalam Sistem Hukum di Indonesia (Jakarta: Sinar Grafika, 1997), 54. According to Sayuti Thalib, the opinion is in accordance with the opinion of Regeerings Reglements (Stastsblad 1884 No. 129 in the Netherlands Jo. S. 1885 No. 2 in Indonesia especially regulated in article 75, article 78 Jo. Article 109 of the RR), at a time it was known as Receptio in complexu.

Article 75 paragraph (3) R.R. reads:

"In case of civil dispute amongst the Indonesian Muslims, it must be treated Gronsdienstig Wetten Islamic law and their customs by Indonesian judge"

Mean while in paragraph (4) of article 75 R.R., it is said that:

"The law of religion, customs and habits were also used for them by European judge in a 'Huger Beroep' court, that in this case, civil cases occur amongst people of Indonesia or those equivalent to an Indonesian, then they submit to religion judge's decision or to the head of their society according to religion law or the existing rules"

According to Article 109 R.R. it is determined that:

"The legal requirements pursuant to Article 75 and Article 78 also apply to those who equalized with those of Indonesia, namely the Arabs, Moors, the Chinese, and all those who are Muslims, and those who are not Muslims".

${ }^{21}$ Muhammad Julijanto, et. al. Etika Islam dan Problematika Sosial di Indonesia (Geneva: Globethics.net Focus No. 6, 2013), 229. 
implemented by integrating Islamic law into state law that is oriented to mashlahah (benefit) in its application by integrating the two legal systems. It can be seen from the idea proposed by Bustanul Arifin as the head of the team in the formation process of Compilation of Islamic Law (KHI), who said the need for Compilation of Islamic Law in Indonesia based on:

1. To be able to enact the (Islamic) law in Indonesia there must be a clear law which can be implemented either by law enforcer or by society.

2. Different perception on the syarî'ah will lead to and have already led to:

2.1. The disagreement in determining things in the Islamic law.

2.2. The absence of clarity on how to run the syarîah.

2.3. Further result which is unable to use the ways and tools that have been provided in the 1945 Constitution and other legislations.

3. There are some countries that integrate Islamic law into state law, in the history.

4. From the perspectives of legal basis, the law of justice has authorized the judge to explore, follow, and understand the values in the community.

5. From the perspective of functional grounding, the Compilation of Islamic Law (KHI) is jurisprudence (figh) compiled by taking the situation of Indonesia into account, it has been pioneered by Hazairin and T.M. Hasbi AshShiddieqy, with a term of Indonesian figh.22

The presence of the Islamic Law Compilation is based on the ideas to integrate Islamic law into the State law in an attempt to answer the needs of Indonesian Muslim community and the mandate of Article 29 paragraph (2) of the 1945 Constitution, which gives a freedom to citizens to practice their religion as a tool that can be used to integrate Islamic law into the state law in Indonesia. In the new paradigm of Islamic Courts in Indonesia, the article 49 of Law No. 7 Year 1989 About the Religious Courts, amended by Law No. 3 of 2006, the Religious Courts have a duty and authority to examine, decide

22 Amin Husein Nasution, Hukum Kewarisan: Suatu Analisis Komperatif Pemikiran Mujtahid dan Kompilasi Hukum Islam (Jakarta: Raja Grafindo, 2012), 10-12. 
and resolve cases at the first level amongst Muslims in the areas of: (a). marriage; (B). inheritance; (C). will; (D). grant; (E). waqf; (F). zakat; (G). infâq; (H). charity; and (i). shari'a economy.

In addition, in view of the Satria Effendi M. Zein, the dynamics of Islamic law takes a place in the join of the flexibility of the legal sources with the dynamics of the followers' creativity. Most importantly, in any forms, the aforementioned principles underlie the life of the Islamic community. Realization of the details may vary, depends on the place and time as well as the development of civilization..$^{23}$ This illustrates that the dynamics must be adapted to the social conditions of the community itself.

\section{Conclusion}

Based on the accounts described above, the value of mashlahah is the basic principle of the maqâshid al-syarîah, Islamic law must be built based on welfare in the sense that is comprehensive, so that people feel that the purpose of the implementation of sharia is aimed at bringing justice for the people in all aspects of life. To achieve mashlahah in the development of Islamic law in Indonesia, then the model integration of Islamic law into the national law is one of the efforts of the developing Islamic law in Indonesia.

The existence of the Compilation Islamic Law which is the needs of Muslims to Islamic law by seeing the condition of Indonesia from the perspective of functional grounding is a part of the idea of integrating Islamic law into national law. In addition, the amendment of Law No. 7 of 1987 by Law No. 3 of 2006, has given the duties and broader authority to the Religious Courts to examine, decide and resolve cases of Muslims. With the flexibility and integration of the two systems of law, the purpose of the Islamic law in Indonesia can gradually be implemented optimally.

\section{BIBLIOGRAPHY:}

Abdurrahman. Kompilasi Hukum Islam di Indonesia. Jakarta: Akademika Pressindo, 1992.

\footnotetext{
23 Ahmad Sukardja, Hukum Tata Negara dan Hukum Administrasi Negara dalam Persepktif Fiqih Siyasah (Jakarta: Sinar Grafika, 2012), 85.
} 
Absori, et. al. Hukum Profetik, Kritik Terhadap Paradigma Hukum Non Sistemik. Yogyakarta: Genta Publishing, 2015.

Asmuni Mth, et.al. Pribumisasi Hukum Islam, Pembacaan Kontemporer Hukum Islam di Indonesia: Perangkat Teoritik dan Metode Perumusan Maqasid Al-Syariah Al-Syatibi. Yogyakarta: Kaukaba, 2012.

Azhari, Aidul Fitriacida. Catatan Kritis Konstitusi, Hukum Tata Negara, Politik, Hukum Islam. Solo: Penerbit Nutrisi Peradaban, 2009.

Dimyati, Khudzaifah. Pemikiran Hukum, Konstruksi Epistimologis Berbasis Budaya Hukum Indonesia. Yogyakarta: Genta Publishing, 2014.

Djalil, Basiq. Peradilan Islam. Jakarta: Amzah, 2012.

Ghufron, A. Mas'adi, Pemikiran Fazlul Rahman tentang Metodologi Pembaharuan Hukum Islam. Jakarta: Rajagrafindo, 1997.

Hilmawan, Anang Haris, et. al. Epistimologi Syar', Mencari Format Baru Fiqih Indonesia. Yogyakarta: Pustaka Pelajar, 2000.

Julijanto, Muhammad, et. al. Etika Islam dan Problematika Sosial di Indonesia. Geneva: Globethics.net Focus No. 6, 2013.

Mustofa and Wahid, Abdul. Hukum Islam Kontemporer. Jakarta: Sinar Grafika, 2013.

Nasution, Amin Husein. Hukum Kewarisan: Suatu Analisis Komperatif Pemikiran Mujtahid dan Kompilasi Hukum Islam. Jakarta: Raja Grafindo, 2012.

Nuruddin, Amiur and Tarigan, Azhari Akmal. Hukum Perdata Islam di Indonesia, (Studi Kritis Perkembangan Hukum Islam dari Fikih, UU No. 1/1974 sampai KIH). Jakarta: Kanana, 2004.

Nursidin, Ghilman. Konstruksi Pemikiran Maqhasid Syariah Imam AlHaramain Al-Juwaini (Kajian Sosio-Histroris), http://eprints.walisongo.ac.id/116/1/Ghilman_Tesis_Sinopsi s.pdf. Accessed April 11, 2015.

Ramulyo, Mohd. Idris. Asas Hukum Islam, Sejarah Timbul dan Berkembangnya Kedudukan Hukum Islam dalam Sistem Hukum di Indonesia. Jakarta: Sinar Grafika, 1997.

Schacht, Joseph. Pengantar Hukum Islam, trans. Joko Supomo. Bandung: Nuansa, 2010.

Shomad, Abd. Hukum Islam Penormaan Prinsip Syariah dalam Hukum di Indonesia. Jakarta: Kencana, 2010. 
Absori, dkk

Siroj, Malthuf. Pembaharuan Hukum Islam di Indonesia, Telaah Kompilasi Hukum Islam. Yogyakarta: Pustaka Ilmu , 2012.

Sukardja, Ahmad. Hukum Tata Negara dan Hukum Administrasi Negara Dalam Persepktif Fiqih Siyasah. Jakarta: Sinar Grafika, 2012.

Tahir, Lukman S. Studi Islam Interdisipliner: Aplikasi Pendekatan Filsafat, Sosiologi dan Sejarah. Jakarta: QIRTAS, 2004. 